Published in final edited form as:

Gastroenterol Clin North Am. 2015 December ; 44(4): 717-734. doi:10.1016/j.gtc.2015.07.003.

\title{
NATURAL HISTORY OF HEPATITIS C
}

\author{
Shilpa Lingala, MD and Marc G. Ghany, MD, MHSc ${ }^{*}$ \\ Liver Diseases Branch, National Institute of Diabetes and Digestive and Kidney Diseases, \\ National Institutes of Health, Bethesda, MD
}

\begin{abstract}
Hepatitis $\mathrm{C}$ infection is a common cause of cirrhosis and indication for liver transplantation in the United States. The incidence of chronic hepatitis $\mathrm{C}$ has been declining but rates of cirrhosis and hepatocellular carcinoma are projected to rise. The outcome of chronic hepatitis $\mathrm{C}$ is variable. It is estimated that $20-25 \%$ will develop cirrhosis over a $25-30$ year period. The rate of disease progression is influenced by may host, viral and environmental factors. Unfortunately, few can be modified.
\end{abstract}

\section{Keywords}

Natural history; hepatitis C virus; chronic hepatitis C; fibrosis; cirrhosis; decompensated liver disease

\section{Introduction}

Hepatitis $\mathrm{C}$ virus infection is an important cause of cirrhosis and hepatocellular carcinoma worldwide (HCC). ${ }^{1}$ It is also a common cause of chronic liver disease in the United States (U.S.) and the leading indication for liver transplantation in the adult U.S. population. The incidence of chronic hepatitis $\mathrm{C}$ is declining in the U.S. but rates of cirrhosis and hepatocellular carcinoma are expected to increase. ${ }^{2}$ Recent data estimate that approximately $1 \%$ of the non-institutionalized U.S. population have chronic HCV infection, corresponding to 2.7 million persons. ${ }^{3}$ Hepatitis $\mathrm{C}$ virus (HCV) is primarily transmitted through parental exposure to blood and other bodily fluids. Following exposure, an acute hepatitis with jaundice occurs in about $20 \%$ of persons although fulminant hepatitis is rare, occurring in less than $1 \%$ of persons. In the majority of cases the acute infection goes unnoticed. Spontaneous resolution may occur in 15-45\% of persons and usually occurs in the first 6 months of exposure. The remainder, develop a chronic hepatitis that has an unpredictable course. Approximately $20-30 \%$ of persons with chronic hepatitis will progress to cirrhosis

\footnotetext{
"Corresponding author: Marc G Ghany, MD, MHSc, Liver Diseases Branch, National Institute of Diabetes and Digestive and Kidney Diseases, National Institutes of Health, Building 10, Room 9B-16, 10 Center Drive, MSC 1800, Bethesda, MD 20892-1800, USA, marcg@ intra.niddk.nih.gov, Telephone: 301-402-5115, Fax 301-402-0491.

Disclosures: Shilpa Lingala and Marc G. Ghany have nothing to disclose.

Publisher's Disclaimer: This is a PDF file of an unedited manuscript that has been accepted for publication. As a service to our customers we are providing this early version of the manuscript. The manuscript will undergo copyediting, typesetting, and review of the resulting proof before it is published in its final citable form. Please note that during the production process errors may be discovered which could affect the content, and all legal disclaimers that apply to the journal pertain.
} 
over a 25-30 year period. The natural history study of chronic hepatitis $\mathrm{C}$ is greatly influenced by host, viral and environmental factors most of which are not modifiable, Table 1. ${ }^{4}$ This article will review the natural history of chronic hepatitis $\mathrm{C}$ and discuss the factors that influence its outcome.

\section{Acute hepatitis C}

The incidence of acute hepatitis $\mathrm{C}$ had been declining in the U.S. but a marked increase in cases was noted between 2010-2013, from 850 in 2010 to 2,138 in 2013, representing a $152 \%$ increase in cases of acute hepatitis $\mathrm{C}$. This sharp rise has been attributed to an increase in injection drug use among the suburban population in the Eastern and Midwestern states.

The most common symptoms of acute hepatitis $\mathrm{C}$ include jaundice, nausea, abdominal pain and flu-like symptoms. In most individuals, HCV RNA is usually detectable within two weeks and anti-HCV antibodies within 12 weeks of exposure to HCV. Serum alanine aminotransferase (ALT) levels usually rise within 8-10 weeks, with a peak ALT of 10-20 times the upper limit of normal. Serum HCV RNA levels may fluctuate widely during the acute phase and even become negative transiently, only to reappear again. This finding is only seen in the acute phase and may be a clinical clue to the diagnosis of acute HCV infection. Spontaneous resolution occurs in 15-25\% of subjects and may be up to $45 \%$ in persons who present with jaundice, children, and young women. Higher rates of spontaneous clearance were also observed in persons with certain polymorphisms (the rs12979860-C ${ }^{5}$ rs8099917- $\mathrm{T}^{6}$ and the ss469415590 $\mathrm{TT}^{7}$ ) near to the IL-28B gene (interferon lambda). HLA class II alleles may play a role in spontaneous clearance. Less genetic diversity of the viral E1 and E2 envelope genes was observed in subjects with spontaneous recovery compared to those who progressed to chronic infection. ${ }^{8}$

\section{Natural History of Chronic Hepatitis C}

Chronic hepatitis $\mathrm{C}$ is defined as persistence of HCV RNA in the blood for more than 6 months after the onset of acute infection. About 55-85\% of patients with acute hepatitis $\mathrm{C}$ transition to chronic hepatitis $\mathrm{C}$, Figure 1. Once the infection becomes chronic, spontaneous resolution is rare. Chronic hepatitis $\mathrm{C}$ can subsequently lead to progressive fibrosis and eventually cirrhosis, end stage liver disease and hepatocellular carcinoma, Figure 1.

It is estimated that $20-30 \%$ patients with chronic hepatitis $\mathrm{C}$ will progress to cirrhosis. However, this rate is highly variable and dependent on the methodology used to define the natural history of the disease, whether prospective, retrospective or retrospective-prospective study designs and the population studied. This was highlighted in an analysis of 57 studies undertaken to estimate progression to cirrhosis. Studies were broadly classified as those from tertiary care liver clinics, post-transfusion cohorts, blood donors and community-based cohorts. Estimates of progression to cirrhosis after 20 years of chronic hepatitis $\mathrm{C}$ varied widely from a high of $24 \%$ for post transfusion cohorts and $22 \%$ for tertiary care liver clinics, to a low of $7 \%$ for community based cohorts and $4 \%$ for blood donors. ${ }^{9}$ Selection bias, recall bias and short duration of follow-up probably account for differences in the 
estimated rate. Community-based cohort studies are likely to provide the best evidence for estimating disease progression at a population level.

Monitoring progression of fibrosis is another way of estimating the outcome of chronic hepatitis C. Since progression of fibrosis is the precursor of cirrhosis, following its progression should reflect the course of the disease. Fibrosis stage was shown to be a good predictor of development cirrhosis and clinical outcomes, need for liver transplantation, and liver-related death, confirming the importance of fibrosis as a surrogate for outcome of chronic hepatitis C. ${ }^{10-12}$ Cross-sectional biopsy studies estimate a period of 30 years to develop cirrhosis. However, since fibrosis progression is unlikely to be linear, performing repeated liver biopsies in subjects should provide a more accurate determination of the rate of progression of fibrosis. Paired liver biopsy studies suggest a time to cirrhosis of 30 to 40 years. ${ }^{11,13-15}$.

\section{Natural History of Cirrhosis}

The development of cirrhosis is an important milestone in the natural history of chronic hepatitis C. Once cirrhosis develops, patients are at risk for decompensation including the development of ascites, spontaneous bacterial peritonitis, variceal hemorrhage and hepatic encephalopathy. Occurrence of any of these events heralds an increased risk of death or need for liver transplantation. Information on the natural history of hepatitis $\mathrm{C}$ after development of cirrhosis has been mostly derived from studies conducted at tertiary referral centers, which may not be representative of all persons with chronic hepatitis C. With this caveat, survival of patients with cirrhosis in the short and medium term is quite good. Five-year survival ranges from $85-91 \%$ with a 10 -year survival of $60-79 \%$. The rate of clinical decompensation is approximately $2-5 \%$ per year and the development of HCC $1-4 \%$ per year. ${ }^{16}$

The HALT-C trial provided important data on the natural history of patients with advanced fibrosis and cirrhosis. ${ }^{17}$ The study treated prior interferon non-responders with 6 months of peginterferon and ribavirin. Failures to this intervention were then randomized to low dose peginterferon or observation for the next 3.5 years. After 4 years of follow-up, outcomes occurred at a similar rate between the treated group, $34.1 \%$ and the control group $33.8 \%$. The most common clinical outcome was an increase of 2 or more points in the ChildTurcotte-Pugh score (documented on two consecutive visits), which occurred in 109 patients $(10.4 \%)$. Ascites was the most common clinical decompensation event that occurred in 59 patients (5.6\%). Hepatocellular carcinoma occurred in 29 patients (2.8\%): $13(2.1 \%)$ in the subjects without and $16(3.7 \%)$ in those with cirrhosis. Fifty-three patients (5.0\%) died, 31 in the treatment group (15 of liver-related causes) and 22 in the control group (12 of liverrelated causes). At 3.8 years, the overall death rate was $6.6 \%$ among patients who received peginterferon and $4.6 \%$ among control patients.

Once decompensation develops, there is an increased risk of death or need for liver transplant. One study followed 200 patients with HCV-related cirrhosis without known HCC after hospitalization for their first hepatic decompensation. ${ }^{18}$ During a mean follow-up of approximately 3 years, HCC developed in $33(16.5 \%)$ patients, and death occurred in 85 
patients (42.5\%). The probability of survival after diagnosis of decompensated cirrhosis was $82 \%$ and $51 \%$ at 1 and 5 years, respectively. ${ }^{18}$ Development of $\mathrm{HE}$ and/or ascites as the first hepatic decompensation event was associated with a lower survival rate.

\section{Factors That Influence The Outcome Of Chronic Hepatitis C}

\section{Host factors}

Age At Infection-Age plays a major role in the progression of fibrosis. Multiple studies have shown that older age at infection was associated with more rapid progression of fibrosis. ${ }^{19-22}$ In one study, nine host, viral and environmental factors were correlated with fibrosis progression among 2,235 untreated patients who underwent liver biopsy. Fibrosis progression per year was defined as the ratio between fibrosis stage in Metavir units and duration of infection in years. Older age at infection $>40$ years, was independently associated with a faster rate of fibrosis progression. ${ }^{19}$

The reasons for the age-related differences in fibrosis progression are not clear. Alteration in physiologic or immunologic status with increasing age may be important. For example a decline in liver volume and liver blood flow with aging or decreased immunologic response might contribute to fibrogenesis or fibrinolysis. ${ }^{16,23}$ Alternatively, older individuals may have a greater prevalence of or exposure to factors associated with fibrosis progression. Based on these data, persons older than 50 years should be monitored more closely for disease progression and considered for treatment earlier in the course of their infection.

Gender-Many studies have shown that females have a higher rate of spontaneous resolution of acute $\mathrm{HCV}$ infection. ${ }^{24-28}$ Among young women who acquired hepatitis C from receipt of contaminated $\mathrm{Rh}$ immune globulin, $45 \%$ cleared the infection spontaneously. Similarly, studies of acute hepatitis $\mathrm{C}$ among drug users have shown that spontaneous clearance was higher among women compared to men. ${ }^{29-32}$

Gender also influences the outcome of chronic infection. Males have a higher risk of progression to advanced liver disease, cirrhosis and HCC when compared to females. Differences in sex hormones have been proposed to explain the gender differences in the progression of the disease. Higher serum testosterone levels were shown to be associated with greater severity of fibrosis. For each $1 \mathrm{ng} / \mathrm{mL}$ increase in total serum testosterone, there was a $25 \%$ increase in risk of advanced fibrosis. ${ }^{33}$ In contrast, estrogen has been proposed to play a protective role in women. ${ }^{34}$ In cross-sectional studies, post-menopausal women (with presumed reduced estrogen levels) had higher rates of fibrosis progression compared to premenopausal women and nulliparous women had higher rates of fibrosis progression compared to multiparous women. ${ }^{35}$ In-vitro data suggest that estrogen can modify extracellular matrix production and attentuate hepatic stellate cell activation resulting in less collagen production.

Race-Chronic hepatitis $\mathrm{C}$ is approximately 3 times more common among non-Hispanic Blacks when compared to non-Hispanic Whites. ${ }^{3}$ The prevalence of hepatitis $\mathrm{C}$ was similar among Latinos and non-Hispanic Whites. African Americans were more likely to be infected with genotype $1,{ }^{36-38}$ have lower baseline serum ALT levels, ${ }^{36-38}$ less piecemeal 
necrosis, ${ }^{36-38}$ less fibrosis, ${ }^{36-38}$ but higher rates of HCC. ${ }^{39}$ Latinos were reported to have more severe necroinflammatory activity compared to non-Hispanic Whites and a higher prevalence of cirrhosis and HCC compared to African-Americans and non-Hispanic Whites. 40-42 A higher prevalence of the metabolic syndrome, insulin resistance, and hepatic steatosis as well as genetic differences among Hispanics are likely important contributing factors. ${ }^{41}$

African Americans and Latinos have lower response rates to interferon-based therapy compared to non-Hispanic whites. ${ }^{43-45}$ A lower prevalence of the favorable IL28b C allele amongst African Americans and Latinos compared to Caucasians and Asians partially accounts for the lower response rates. ${ }^{5}$ Differences in HLA class II alleles influencing host immune response to the virus may also contribute to the racial differences in viral clearance. 46,47

Obesity-Obesity, defined as a BMI greater than $30 \mathrm{~kg} / \mathrm{m}^{2}$ is an independent risk factor for fibrosis progression and development of cirrhosis. In one study, subjects undergoing liver biopsy were classified as rapid or non-rapid progressors based on a fibrosis progression rate of $>0.2$ fibrosis units/year. It was shown that BMI > 25 was predictive of rapid fibrosis progression. ${ }^{48}$ Steatohepatitis associated with obesity and increasing circulating insulin levels are thought to be contributing factors responsible for fibrosis progression in chronic hepatitis $\mathrm{C}$ irrespective of the genotype ${ }^{49}$ Obesity is also found to be a risk factor for nonresponse to antiviral therapy independent of steatosis, genotype and the presence of cirrhosis. Obese individuals have an $80 \%$ lower chance of a sustained response to interferonbased therapy compared with normal or overweight patients. ${ }^{50}$

Steatosis-Hepatic steatosis is a common finding among the general population ranging from $10-24 \%$. Using the presence of fat on ultrasound as a surrogate for steatosis, the prevalence of steatosis was $21 \%$ in the NHANES-3 study of the non-institutionalized U.S. population. ${ }^{51}$ The prevalence of steatosis is approximately 2-3 times more common in persons with chronic hepatitis $\mathrm{C}$ ranging from $42-70 \% .{ }^{52-56}$ The etiology of steatosis in patients with hepatitis $\mathrm{C}$ is multifactorial resulting from metabolic derangements in the host due to obesity but also due to $\mathrm{HCV}$ infection itself. Hepatic steatosis has been suggested to promote the development of fibrosis and hasten progression to cirrhosis, increase the risk for HCC and lower the response to interferon-based therapy. Non-alcoholic steatohepatitis (NASH) represents a more advanced form of steatosis and has been associated with progressive liver disease and cirrhosis. Therefore, co-existent NASH and chronic hepatitis $\mathrm{C}$ may result in more rapid progression of liver disease. Given these adverse consequences of steatosis and NASH, patients with hepatitis $\mathrm{C}$ should try to maintain an ideal body weight.

Insulin Resistance/Diabetes-Diabetes mellitus is a common co-morbity in subjects with chronic hepatitis $\mathrm{C}$ ranging from $24-62 \% .{ }^{57,58}$ The development of insulin resistance (IR)/diabetes in patients with chronic hepatitis $\mathrm{C}$ is complex and appears to be related to presence of the metabolic syndrome as well as a result of the viral infection both of which may independently lead to the development of cirrhosis. Two meta-analyses have suggested a strong association between chronic hepatitis $\mathrm{C}$ and the development of insulin resistance. ${ }^{59,60}$ However, some studies have found no association between chronic hepatitis $\mathrm{C}$ and pre- 
diabetes or diabetes. Rather an association was found with elevated ALT and gamma glutamyl transpeptidase levels suggesting that inflammation per se may lead to IR and diabetes. ${ }^{61}$ Interestingly, eradication of $\mathrm{HCV}$ has been associated with improvement and even reversal of insulin resistance ${ }^{62-64}$ and diabetes. ${ }^{65}$

Insulin resistance and diabetes are associated with faster progression fibrosis, increased risk of cirrhosis and its complications including HCC and lower response to therapy in patients with chronic hepatitis $\mathrm{C}$. In one study of patients with cirrhosis, the presence of diabetes was an independent risk factor for decompensation, liver transplantation, and death. A population-based study from Taiwan reported that new-onset diabetes was an independent predictor of cirrhosis and hepatic decompensation. These findings suggest but do not prove that better control of diabetes or insulin resistance could lead to better outcomes among patients with chronic hepatitis $\mathrm{C}$ including those with cirrhosis.

Genetics-Although several host, viral, and environmental factors have been linked with outcome of CHC, they do not completely explain the variable outcome of the disease. A strong host immune response against HCV favors viral clearance. Therefore, variability in genes involved in the immune response may contribute to viral clearance. In a landmark study, a genetic polymorphism near the IL28B gene, encoding interferon-lambda-3 (IFNlambda-3), was shown to be strongly associated with response to treatment with interferon and spontaneous clearance of HCV. ${ }^{5}$ The C allele of rs 12979860 and G allele of rs8099917 were associated with an almost two-fold change in treatment-related clearance of HCV compared to the T allele at both loci. ${ }^{5}$ This observation was true for individuals of both European and African ancestry. In another study of 1,015 subjects with chronic infection and 347 who spontaneously cleared the infection, the minor allele $(\mathrm{G})$ of the SNP at position rs8099917 was associated with a greater than 2-fold progression to chronic $\mathrm{HCV}$ infection. ${ }^{66}$ The IL28B CC genotype was also shown to be associated with greater hepatic necroinflammation, higher ALT, and worse clinical outcomes in subjects with chronic hepatitis $\mathrm{C} .{ }^{67}$ Other genetic factors also play a role in outcome of $\mathrm{HCV}$ infection but are beyond the scope of this review.

ALT levels-In population studies, increasing ALT levels were shown to be associated with a progressive increase in death from all causes and in particular liver-related death. ${ }^{68}$ Persistently normal ALT levels are found in approximately 20-30\% of patients with chronic hepatitis. ${ }^{69,70}$ Subjects with persistently normal ALT levels are more likely to have mild liver fibrosis on liver biopsy. In a review of 23 studies with over 1,100 subjects, $80 \%$ of subjects with a normal ALT level had mild fibrosis whereas only $20 \%$ had advanced fibrosis. ${ }^{71}$ Additionally, subjects with normal ALT levels progress at a much slower rate when compared to those with elevated ALT levels. ${ }^{72-75}$

In cross-sectional biopsy studies, serum ALT was not predictive of severity of fibrosis. However, in paired liver biopsies, elevated ALT levels were associated with progression of fibrosis. ${ }^{11-13,14}$ Serum ALT was not predictive of development of clinical outcomes, however the AST/ALT ratio was predictive. ${ }^{76}$ Patients with elevated serum ALT levels are also found to have increased risk for hepatocellular carcinoma. In a large Taiwanese study, the cumulative risk for HCC was $1.7 \%$ for ALT levels $\leq 15 \mathrm{U} / \mathrm{L}$ and increased to $4.2 \%$ levels 
between 15-45 U/L and to $13.8 \%$ for ALT levels $\geq 45 \mathrm{U} / \mathrm{L} .{ }^{77}$ Therefore, monitoring of ALT levels is useful in managing chronic hepatitis $\mathrm{C}$.

Exercise-Weight loss and exercise are known to cause reduction in steatosis, obesity, diabetes and insulin resistance leading to improvement in serum ALT levels and fibrosis, despite the persistence of the HCV RNA. The potential benefits of exercise in patients with chronic hepatitis $\mathrm{C}$ were shown in a study of 16 obese patients with chronic hepatitis $\mathrm{C}$. Dietary intervention and increased exercise were associated with reduction in BMI, improved insulin sensitivity and serum ALT and AST levels suggesting that dietary and exercise intervention may improve hepatic and metabolic status in obese insulin-resistant CHC. ${ }^{78}$ The intensity and type of exercise may be important to derive the beneficial effects. High intensity aerobic exercise training was shown to improve hepatic enzymes and also psychological well-being in patients with chronic hepatitis C. Aerobic exercise has also been shown to improve psychological well-being and quality of life in overweight and obese patients with CHC. ${ }^{79,80}$ Therefore, recommending exercise should be an important component in the management of chronic hepatitis $\mathrm{C}$.

\section{Viral Factors}

HCV RNA Level-Unlike HIV infection, there is little evidence to support the notion that HCV viral load affects outcome of chronic hepatitis $C$. The viral load observed among persons with chronic hepatitis $\mathrm{C}$ usually ranges from $10^{4}$ to $10^{8}$ copies $/ \mathrm{mL}$ with an average HCV RNA level of approximately $10^{6}$ copies $/ \mathrm{mL} .{ }^{81} \mathrm{HCV}$-RNA levels tend to remain relatively stable when serial determinations were made over time and rarely fluctuate above or below $1 \log$ of the baseline. HCV viral load does not differ among viral genotypes. ${ }^{82}$ The majority of studies have shown no correlation between HCV RNA level and histological outcome. ${ }^{83-85}$ Therefore, there is no role for serially assessing viral load in a patient. Viral load is predictive of response to treatment with lower viral load being associated with higher response rates.

HCV Quasispecies/Genotype-The HCV polymerase lacks proof reading capacity, as a result many errors are introduced during replication. Consequently, the virus circulates as a viral swarm or quasispecies. Viral quasispecies were shown to affect spontaneous viral clearance. ${ }^{8}$ Lower genetic diversity of the envelope region was associated with a higher rate of spontaneous clearance.

Six major genotypes have been identified based on a sequence divergence of $30 \%$ among isolates. $\mathrm{HCV}$ genotypes have a geographical distribution with genotype 1 being the most common worldwide, accounting for $46 \%$ of all $\mathrm{HCV}$ cases, approximately one-third of which are in East Asia. Genotype 3 is the next most prevalent globally, 30\%. Genotypes 2, 4, and 6 are responsible for a total $23 \%$ of all cases and the remaining cases are comprised of genotype $5 .{ }^{86}$ The association between HCV genotype and disease progression is not very clear. A meta-analysis of 16 studies suggested that HCV genotype 3 was associated with accelerated fibrosis progression in single biopsy studies but not paired biopsy studies. ${ }^{87}$ It is possible that steatosis associated with genotype 3 , an independent predictor of fibrosis progression, might be the cause of the fibrosis progression rather than the HCV genotype 3 
itself. The most important clinical utility of HCV genotype is as a predictor of response to therapy. The development of $\mathrm{HCV}$ regimens with pangenotypic activity may preclude the need for genotyping altogether.

Co-infection With HBV-Hepatitis C virus shares similar routes of transmission as HBV, so coinfection with these viruses is not uncommon. The prevalence of $\mathrm{HBV} / \mathrm{HCV}$ coinfection is about $2-10 \%$ but there is significant geographical variation. ${ }^{88-95}$ Interestingly, most studies of HBV-HCV co-infected subjects show that usually only a single virus predominates though which one was unpredictable. ${ }^{96,97}$ Several studies have shown that coinfected patients are at substantially higher risk for cirrhosis, HCC and overall mortality compared to $\mathrm{HCV}$ monoinfected patients. In a large U.S. cohort study, a significantly increased risk of cirrhosis ( $\sim 89 \%$ increase), HCC ( $112 \%$ increase), and death ( $62 \%$ increase) were seen in HBV/HCV coinfected patients who were HBV DNA positive when compared to monoinfected patients whereas the absence of HBV replication was associated with a clinical course similar to that of HCV monoinfected patients. ${ }^{98}$ Therefore, patients with $\mathrm{HBV}$ and $\mathrm{HCV}$ coinfection require close monitoring for the development of cirrhosis and may warrant more intensive HCC screening.

Co-infection with HIV-CV and HIV share similar routes of transmission. The overall burden of HIV/HCV coinfection is estimated at 4 to 5 million people worldwide. ${ }^{99}$ The prevalence of $\mathrm{HIV} / \mathrm{HCV}$ varies geographically and by the mode of transmission. The highest rates are seen in injection drug users and men who have sex with men. HCV infection is not associated with an increased rate of AIDS-defining events or deaths. ${ }^{100}$ However, HIV has a number of adverse consequences on the outcome of $\mathrm{HCV}$ infection. HIV has been shown to increase the rate of chronic HCV infection, ${ }^{101,102}$ to increase HCV RNA levels ${ }^{81,101,103,104}$ and is associated with faster progression of fibrosis and development of cirrhosis. Response rates to interferon-based treatment are also lower among co-infected persons. Prior to HAART therapy, most co-infected individuals died from complications of HIV infection. However, in the post-HAART era, HCV-related liver disease (primarily end-stage liver disease) is a major cause of death among co-infected persons. ${ }^{105,106} \mathrm{HIV}$ has been shown to accelerate progression of fibrosis among persons with chronic hepatitis $\mathrm{C}$, including those with persistently normal ALT levels. ${ }^{107,108}$ Approximately, one-third of persons with HIV$\mathrm{HCV}$ co-infection progress to cirrhosis over a 20 year period and about $50 \%$ will progress to cirrhosis over a 30 year period compared to $25 \%$ over 25 to 30 year period among monoinfected subjects. ${ }^{109}$

\section{Environmental factors}

Alcohol-There are limited data on the prevalence of alcohol use among persons with chronic hepatitis C. A large meta-analysis of 111 studies which included 33,121 subjects, conducted to examine progression of fibrosis, reported that $19 \%$ of subjects consumed alcohol ranging from $20 \mathrm{~g} /$ day to $80 \mathrm{~g} /$ day. ${ }^{110}$ The prevalence of chronic hepatitis $\mathrm{C}$ appears to be 5-10 fold higher among persons with a history of alcohol abuse. Alcohol consumption is known to adversely affect the outcome of HCV infection: it has been associated with faster progression of liver fibrosis, higher frequency of cirrhosis, and increased incidence of hepatocellular carcinoma. Subjects with $\mathrm{HCV}$ who abuse alcohol have decreased survival as 
compared with patients with either alcohol abuse or HCV liver injury alone. Alcohol consumption may be the single most important factor affecting disease progression in patients with chronic hepatitis $C$. Seeff et al. have reported that more than two thirds of deaths with end-stage liver disease secondary to non-A, non-B hepatitis occurred in alcoholic patients. ${ }^{4}$

An alcohol intake between 30-80 g/day has been shown to cause progression of liver disease. ${ }^{111}$ In one study, mean fibrosis stage was significantly higher and progression of fibrosis higher in patients whose daily alcohol consumption was $50 \mathrm{~g}$ or more than in those who consumed less than $50 \mathrm{~g}$, irrespective of age or duration of infection. ${ }^{19}$ A large metaanalysis conducted to explore the relationship between advanced liver disease and alcohol use taking into account the different definitions of heavy alcohol consumption across many studies, including more than 15,000 patients with HCV infection, demonstrated that heavy intake between 210 and $560 \mathrm{~g} /$ week was associated with a 2.3 fold increase risk of cirrhosis. 112 It was also shown that even moderate alcohol consumption, as low as $31-50 \mathrm{~g} /$ day in men and 21-50 g/day in women, might worsen histological activity and fibrosis in HCVinfected patients. ${ }^{113}$ The mechanism by which alcohol causes the progression of the disease is not very clear. Immune dysfunction, increased viral replication, emergence of HCV quasispecies, apoptotis, steatosis and increased iron overload have been proposed. ${ }^{113}$ Currently, there is insufficient evidence to determine a "safe" amount of alcohol use. Therefore, despite the beneficial cardiovascular effects of light alcohol use (10-20 g/day), given the uncertainty on the effects of this amount of alcohol on liver disease progression, patients should be counseled of the adverse effects of alcohol on outcome of chronic hepatitis $\mathrm{C}$ and advised to refrain from alcohol use.

Smoking-Whether smoking has any affect on outcome of chronic hepatitis $\mathrm{C}$ is uncertain. Smoking > 15 pack years was shown to be an independent predictor of liver fibrosis but this association was lost when disease activity was controlled for in a multivariate analysis. 114 Tobacco use higher than $15 \mathrm{cig} /$ day was associated with more severe histological activity in patients with chronic hepatitis $\mathrm{C}$. In one study, the proportion of patients with moderate and marked activity (Metavir A2-A3) increased gradually from 62\% in patients who did not smoke to $82 \%$ in patients who smoked more than 15 cigarettes/day 6 months before biopsy. 115 Release of proinflammatory cytokines, lipid peroxidation, oxidative stress, steatosis and iron overload from secondary polycythemia are thought to be the mechanisms by which smoking causes progression of liver disease. ${ }^{116}$ Tobacco use is also known to independently contribute to the development of HCC. Indeed, alcohol, smoking and obesity act synergistically in the development of HCC. ${ }^{117}$ Although the evidence for smoking on outcome of $\mathrm{HCV}$ infection is weak, patients with chronic hepatitis $\mathrm{C}$ should be advised to not smoke.

Cannabis-There is both clinical and experiment evidence indicating that daily cannabis use is a co-factor modulating disease progression in patients with chronic hepatitis $\mathrm{C}$. Several studies have reported a strong association between cannabis use and significant fibrosis ( $₫$ Metavir F3). In one study from France, 270 consecutive patients with chronic hepatitis $\mathrm{C}$ undergoing liver biopsy were studied. Categorizing cannabis use as none, 
occasional or daily, daily cannabis use was associated with severe fibrosis on biopsy and a faster rate of fibrosis progression. ${ }^{118}$ The $\mathrm{CB}_{1}$ receptor is widely expressed in the human liver and its up-regulation is associated with steatosis and advanced fibrosis. ${ }^{18-120}$ Furthermore, daily cannabis use and moderate to heavy alcohol use have additive effects in fibrosis progression. ${ }^{120}$ Therefore, patients with chronic hepatitis $\mathrm{C}$ should abstain from use of cannabis.

Caffeine-Multiple epidemiological studies from different geographical regions have reported an association between daily caffeine consumption and lower risk of an elevated ALT level in persons without liver disease or at high risk for liver disease. ${ }^{121-123}$ Coffee consumption has also been associated with a lower risk of advanced liver disease, cirrhosis and hepatocellular carcinoma in patients with chronic liver disease. In one study, 177 patients scheduled to undergo liver biopsy were asked to complete a detailed caffeine questionnaire on three occasions over a 6-month period. Caffeine intake was correlated with severity of liver disease. A daily caffeine consumption >308 (equivalent to 2.25 cups/day) was associated with less severe hepatic fibrosis. ${ }^{124}$ Interestingly, caffeine from other sources such as tea or caffeinated beverages was not associated with stage of liver fibrosis. ${ }^{124}$ Although the evidence of the protective effects of coffee/caffeine on liver disease is growing, no prospective trials have been conducted on the use of caffeine/coffee to improve liver disease. In addition, since the amount of caffeine varies considerable from cup to cup of coffee the amount of caffeine that is required for a beneficial effect is unknown. Until more data is forthcoming we cannot recommend that patients with chronic hepatitis $\mathrm{C}$ use caffeine/coffee excessively.

Herbals-In the United States, silymarin (an extract of milk thistle) is the most popular herbal product used by persons with liver disease. The HALT-C trial examined the frequency and the potential effects of herbal supplments in a large cohort of patients with advanced chronic hepatitis C. Silymarin was found to be the most frequently used herbal supplement. Silymarin had no benefical effect on ALT or HCV RNA levels but users reported fewer and milder symptoms of liver disease and better overall quality of life. Silymarin users had similar ALT and HCV levels to those of nonusers. ${ }^{125}$ Further analysis of the HALT-C trial dataset demonstrated that silymarin use was associated with reduced progression to cirrhosis but had no impact on clinical outcomes. ${ }^{126}$ Silymarin was also evaluated in a randomized controlled trial to improve disease activity using serum ALT as a surrogate in subjects who had previously failed interferon-based therapy. Higher than usual doses of silymarin had no benefit on reducing serum ALT levels in persons who failed to respond to prior interferonbased therapy and its use cannot be recommend in this population. ${ }^{127}$ Another herbal compound, glycyrrhizin used in Japan was reported to lower ALT levels and also prevent carcinogenesis. ${ }^{128}$ Currently, there is little evidence to support the use of herbals to improve outcome of chronic hepatitis $\mathrm{C}$.

\section{Conclusion}

In conclusion, the natural history of hepatitis $C$ virus is influenced by a wide variety of host, viral and environmental factors. Physicians should seek to identify these factors to risk 
stratify patients. In addition, patients should be counseled to improve modifiable ones to limit disease progression.

\section{Acknowledgments}

Financial Support: This work was supported by the Intramural Program of the National Institute of Diabetes and Digestive and Kidney Diseases, National Institutes of Health.

\section{References}

1. Lozano R, Naghavi M, Foreman K, et al. Global and regional mortality from 235 causes of death for 20 age groups in 1990 and 2010: a systematic analysis for the Global Burden of Disease Study 2010. Lancet. Dec 15; 2012 380(9859):2095-2128. [PubMed: 23245604]

2. Davis GL, Alter MJ, El-Serag H, Poynard T, Jennings LW. Aging of hepatitis C virus (HCV)infected persons in the United States: a multiple cohort model of HCV prevalence and disease progression. Gastroenterology. Feb; 2010 138(2):513-521. 521 e511-516. [PubMed: 19861128]

3. Denniston MM, Jiles RB, Drobeniuc J, et al. Chronic hepatitis C virus infection in the United States, National Health and Nutrition Examination Survey 2003 to 2010. Annals of internal medicine. Mar 4; 2014 160(5):293-300. [PubMed: 24737271]

4. Seeff LB. The natural history of chronic hepatitis $\mathrm{C}$ virus infection. Clinics in liver disease. Nov; 1997 1(3):587-602. [PubMed: 15560060]

5. Ge D, Fellay J, Thompson AJ, et al. Genetic variation in IL28B predicts hepatitis C treatmentinduced viral clearance. Nature. Sep 17; 2009 461(7262):399-401. [PubMed: 19684573]

6. Tanaka Y, Nishida N, Sugiyama M, et al. Genome-wide association of IL28B with response to pegylated interferon-alpha and ribavirin therapy for chronic hepatitis C. Nature genetics. Oct; 2009 41(10):1105-1109. [PubMed: 19749757]

7. Prokunina-Olsson L, Muchmore B, Tang W, et al. A variant upstream of IFNL3 (IL28B) creating a new interferon gene IFNL4 is associated with impaired clearance of hepatitis $C$ virus. Nature genetics. Feb; 2013 45(2):164-171. [PubMed: 23291588]

8. Farci P, Shimoda A, Coiana A, et al. The outcome of acute hepatitis $\mathrm{C}$ predicted by the evolution of the viral quasispecies. Science. Apr 14; 2000 288(5464):339-344. [PubMed: 10764648]

9. Freeman AJ, Dore GJ, Law MG, et al. Estimating progression to cirrhosis in chronic hepatitis C virus infection. Hepatology. Oct; 2001 34(4 Pt 1):809-816. [PubMed: 11584380]

10. Yano M, Kumada H, Kage M, et al. The long-term pathological evolution of chronic hepatitis C. Hepatology. Jun; 1996 23(6):1334-1340. [PubMed: 8675148]

11. Ghany MG, Kleiner DE, Alter H, et al. Progression of fibrosis in chronic hepatitis C. Gastroenterology. Jan; 2003 124(1):97-104. [PubMed: 12512034]

12. Everhart JE, Wright EC, Goodman ZD, et al. Prognostic value of Ishak fibrosis stage: findings from the hepatitis $\mathrm{C}$ antiviral long-term treatment against cirrhosis trial. Hepatology. Feb; 2010 51(2):585-594. [PubMed: 20101752]

13. Boccato S, Pistis R, Noventa F, Guido M, Benvegnu L, Alberti A. Fibrosis progression in initially mild chronic hepatitis C. Journal of viral hepatitis. May; 2006 13(5):297-302. [PubMed: 16637859]

14. Marcellin P, Asselah T, Boyer N. Fibrosis and disease progression in hepatitis C. Hepatology. Nov; 2002 36(5 Suppl 1):S47-56. [PubMed: 12407576]

15. Ryder SD, Irving WL, Jones DA, Neal KR, Underwood JC, Trent Hepatitis CSG. Progression of hepatic fibrosis in patients with hepatitis C: a prospective repeat liver biopsy study. Gut. Mar; 2004 53(3):451-455. [PubMed: 14960533]

16. Fattovich G, Giustina G, Degos F, et al. Morbidity and mortality in compensated cirrhosis type C: a retrospective follow-up study of 384 patients. Gastroenterology. Feb; 1997 112(2):463-472. [PubMed: 9024300] 
17. Di Bisceglie AM, Shiffman ML, Everson GT, et al. Prolonged therapy of advanced chronic hepatitis $C$ with low-dose peginterferon. The New England journal of medicine. Dec 4; 2008 359(23):2429-2441. [PubMed: 19052125]

18. Planas R, Balleste B, Alvarez MA, et al. Natural history of decompensated hepatitis C virus-related cirrhosis. A study of 200 patients. Journal of hepatology. May; 2004 40(5):823-830. [PubMed: 15094231]

19. Poynard T, Bedossa P, Opolon P. Natural history of liver fibrosis progression in patients with chronic hepatitis C. The OBSVIRC, METAVIR, CLINIVIR, and DOSVIRC groups. Lancet. Mar 22; 1997 349(9055):825-832. [PubMed: 9121257]

20. Minola E, Prati D, Suter F, et al. Age at infection affects the long-term outcome of transfusionassociated chronic hepatitis C. Blood. Jun 15; 2002 99(12):4588-4591. [PubMed: 12036892]

21. Pradat P, Voirin N, Tillmann HL, Chevallier M, Trepo C. Progression to cirrhosis in hepatitis C patients: an age-dependent process. Liver international : official journal of the International Association for the Study of the Liver. Apr; 2007 27(3):335-339. [PubMed: 17355454]

22. Wright M, Goldin R, Fabre A, et al. Measurement and determinants of the natural history of liver fibrosis in hepatitis C virus infection: a cross sectional and longitudinal study. Gut. Apr; 2003 52(4):574-579. [PubMed: 12631672]

23. Kanwal F, Hoang T, Kramer JR, et al. Increasing prevalence of HCC and cirrhosis in patients with chronic hepatitis C virus infection. Gastroenterology. Apr; 2011 140(4):1182-1188. e1181. [PubMed: 21184757]

24. Bakr I, Rekacewicz C, El Hosseiny M, et al. Higher clearance of hepatitis C virus infection in females compared with males. Gut. Aug; 2006 55(8):1183-1187. [PubMed: 16434426]

25. Wang CC, Krantz E, Klarquist J, et al. Acute hepatitis C in a contemporary US cohort: modes of acquisition and factors influencing viral clearance. The Journal of infectious diseases. Nov 15; 2007 196(10):1474-1482. [PubMed: 18008226]

26. Guadagnino V, Stroffolini T, Rapicetta M, et al. Prevalence, risk factors, and genotype distribution of hepatitis $\mathrm{C}$ virus infection in the general population: a community-based survey in southern Italy. Hepatology. Oct; 1997 26(4):1006-1011. [PubMed: 9328327]

27. Cox AL, Netski DM, Mosbruger T, et al. Prospective evaluation of community-acquired acutephase hepatitis $\mathrm{C}$ virus infection. Clinical infectious diseases : an official publication of the Infectious Diseases Society of America. Apr 1; 2005 40(7):951-958. [PubMed: 15824985]

28. Alter MJ, Kruszon-Moran D, Nainan OV, et al. The prevalence of hepatitis C virus infection in the United States, 1988 through 1994. The New England journal of medicine. Aug 19; 1999 341(8): 556-562. [PubMed: 10451460]

29. van den Berg CH, Grady BP, Schinkel J, et al. Female sex and IL28B, a synergism for spontaneous viral clearance in hepatitis $\mathrm{C}$ virus (HCV) seroconverters from a community-based cohort. PloS one. 2011; 6(11):e27555. [PubMed: 22110669]

30. Page K, Hahn JA, Evans J, et al. Acute hepatitis C virus infection in young adult injection drug users: a prospective study of incident infection, resolution, and reinfection. The Journal of infectious diseases. Oct 15; 2009 200(8):1216-1226. [PubMed: 19764883]

31. Grebely J, Page K, Sacks-Davis R, et al. The effects of female sex, viral genotype, and IL28B genotype on spontaneous clearance of acute hepatitis C virus infection. Hepatology. Jan; 2014 59(1):109-120. [PubMed: 23908124]

32. Mosley JW, Operskalski EA, Tobler LH, et al. The course of hepatitis C viraemia in transfusion recipients prior to availability of antiviral therapy. Journal of viral hepatitis. Feb; 2008 15(2):120128. [PubMed: 18184195]

33. White DL, Tavakoli-Tabasi S, Kuzniarek J, Pascua R, Ramsey DJ, El-Serag HB. Higher serum testosterone is associated with increased risk of advanced hepatitis C-related liver disease in males. Hepatology. Mar; 2012 55(3):759-768. [PubMed: 21858849]

34. White DL, Liu Y, Garcia J, et al. Sex hormone pathway gene polymorphisms are associated with risk of advanced hepatitis C-related liver disease in males. International journal of molecular epidemiology and genetics. 2014; 5(3):164-176. [PubMed: 25379136] 
35. Di Martino V, Lebray P, Myers RP, et al. Progression of liver fibrosis in women infected with hepatitis C: long-term benefit of estrogen exposure. Hepatology. Dec; 2004 40(6):1426-1433. [PubMed: 15565616]

36. Wiley TE, Brown J, Chan J. Hepatitis C infection in African Americans: its natural history and histological progression. The American journal of gastroenterology. Mar; 2002 97(3):700-706. [PubMed: 11922566]

37. Sterling RK, Stravitz RT, Luketic VA, et al. A comparison of the spectrum of chronic hepatitis C virus between Caucasians and African Americans. Clinical gastroenterology and hepatology : the official clinical practice journal of the American Gastroenterological Association. Jun; 2004 2(6): 469-473. [PubMed: 15181614]

38. Crosse K, Umeadi OG, Anania FA, et al. Racial differences in liver inflammation and fibrosis related to chronic hepatitis C. Clinical gastroenterology and hepatology : the official clinical practice journal of the American Gastroenterological Association. Jun; 2004 2(6):463-468. [PubMed: 15181613]

39. El-Serag HB. Hepatocellular carcinoma and hepatitis C in the United States. Hepatology. Nov; 2002 36(5 Suppl 1):S74-83. [PubMed: 12407579]

40. Bonacini M, Groshen MD, Yu MC, Govindarajan S, Lindsay KL. Chronic hepatitis C in ethnic minority patients evaluated in Los Angeles County. The American journal of gastroenterology. Aug; 2001 96(8):2438-2441. [PubMed: 11513187]

41. Rodriguez-Torres M. Latinos and chronic hepatitis C: a singular population. Clinical gastroenterology and hepatology : the official clinical practice journal of the American Gastroenterological Association. May; 2008 6(5):484-490. [PubMed: 18455693]

42. El-Serag HB, Kramer J, Duan Z, Kanwal F. Racial differences in the progression to cirrhosis and hepatocellular carcinoma in HCV-infected veterans. The American journal of gastroenterology. Sep; 2014 109(9):1427-1435. [PubMed: 25070058]

43. Conjeevaram HS, Fried MW, Jeffers LJ, et al. Peginterferon and ribavirin treatment in African American and Caucasian American patients with hepatitis C genotype 1. Gastroenterology. Aug; 2006 131(2):470-477. [PubMed: 16890601]

44. Muir AJ, Hu KQ, Gordon SC, et al. Hepatitis C treatment among racial and ethnic groups in the IDEAL trial. Journal of viral hepatitis. Apr; 2011 18(4):e134-143. [PubMed: 21108699]

45. Rodriguez-Torres M, Jeffers LJ, Sheikh MY, et al. Peginterferon alfa-2a and ribavirin in Latino and non-Latino whites with hepatitis C. The New England journal of medicine. Jan 15; 2009 360(3): 257-267. [PubMed: 19144941]

46. Thio CL, Thomas DL, Goedert JJ, et al. Racial differences in HLA class II associations with hepatitis C virus outcomes. The Journal of infectious diseases. Jul 1; 2001 184(1):16-21. [PubMed: 11398104]

47. Sugimoto K, Stadanlick J, Ikeda F, et al. Influence of ethnicity in the outcome of hepatitis C virus infection and cellular immune response. Hepatology. Mar; 2003 37(3):590-599. [PubMed: 12601357]

48. Ortiz V, Berenguer M, Rayon JM, Carrasco D, Berenguer J. Contribution of obesity to hepatitis Crelated fibrosis progression. The American journal of gastroenterology. Sep; 2002 97(9):24082414. [PubMed: 12358265]

49. Hickman IJ, Powell EE, Prins JB, et al. In overweight patients with chronic hepatitis C, circulating insulin is associated with hepatic fibrosis: implications for therapy. Journal of hepatology. Dec; 2003 39(6):1042-1048. [PubMed: 14642624]

50. Bressler BL, Guindi M, Tomlinson G, Heathcote J. High body mass index is an independent risk factor for nonresponse to antiviral treatment in chronic hepatitis C. Hepatology. Sep; 2003 38(3): 639-644. [PubMed: 12939590]

51. Lazo M, Hernaez R, Eberhardt MS, et al. Prevalence of nonalcoholic fatty liver disease in the United States: the Third National Health and Nutrition Examination Survey, 1988-1994. American journal of epidemiology. Jul 1; 2013 178(1):38-45. [PubMed: 23703888]

52. Hourigan LF, Macdonald GA, Purdie D, et al. Fibrosis in chronic hepatitis C correlates significantly with body mass index and steatosis. Hepatology. Apr; 1999 29(4):1215-1219. [PubMed: 10094967] 
53. Adinolfi LE, Gambardella M, Andreana A, Tripodi MF, Utili R, Ruggiero G. Steatosis accelerates the progression of liver damage of chronic hepatitis $\mathrm{C}$ patients and correlates with specific HCV genotype and visceral obesity. Hepatology. Jun; 2001 33(6):1358-1364. [PubMed: 11391523]

54. Monto A, Alonzo J, Watson JJ, Grunfeld C, Wright TL. Steatosis in chronic hepatitis C: relative contributions of obesity, diabetes mellitus, and alcohol. Hepatology. Sep; 2002 36(3):729-736. [PubMed: 12198667]

55. Perumalswami P, Kleiner DE, Lutchman G, et al. Steatosis and progression of fibrosis in untreated patients with chronic hepatitis C infection. Hepatology. Apr; 2006 43(4):780-787. [PubMed: 16557550]

56. Leandro G, Mangia A, Hui J, et al. Relationship between steatosis, inflammation, and fibrosis in chronic hepatitis C: a meta-analysis of individual patient data. Gastroenterology. May; 2006 130(6):1636-1642. [PubMed: 16697727]

57. Grimbert S, Valensi P, Levy-Marchal C, et al. High prevalence of diabetes mellitus in patients with chronic hepatitis C. A case-control study. Gastroenterologie clinique et biologique. 1996; 20(6-7): 544-548. [PubMed: 8881566]

58. Mehta SH, Brancati FL, Sulkowski MS, Strathdee SA, Szklo M, Thomas DL. Prevalence of type 2 diabetes mellitus among persons with hepatitis C virus infection in the United States. Annals of internal medicine. Oct 17; 2000 133(8):592-599. [PubMed: 11033586]

59. White DL, Ratziu V, El-Serag HB. Hepatitis C infection and risk of diabetes: a systematic review and meta-analysis. Journal of hepatology. Nov; 2008 49(5):831-844. [PubMed: 18814931]

60. Naing C, Mak JW, Ahmed SI, Maung M. Relationship between hepatitis C virus infection and type 2 diabetes mellitus: meta-analysis. World J Gastroenterol. Apr 14; 2012 18(14):1642-1651. [PubMed: 22529694]

61. Ruhl CE, Menke A, Cowie CC, Everhart JE. Relationship of hepatitis C virus infection with diabetes in the U.S. population. Hepatology. Oct; 2014 60(4):1139-1149. [PubMed: 24500979]

62. Kim HJ, Park JH, Park DI, et al. Clearance of HCV by Combination Therapy of Pegylated Interferon alpha-2a and Ribavirin Improves Insulin Resistance. Gut Liver. Jun; 2009 3(2):108-115. [PubMed: 20431732]

63. Delgado-Borrego A, Jordan SH, Negre B, et al. Reduction of insulin resistance with effective clearance of hepatitis $\mathrm{C}$ infection: results from the HALT-C trial. Clinical gastroenterology and hepatology : the official clinical practice journal of the American Gastroenterological Association. May; 2010 8(5):458-462. [PubMed: 20156586]

64. Butt AA, Umbleja T, Andersen JW, Sherman KE, Chung RT. Impact of peginterferon alpha and ribavirin treatment on lipid profiles and insulin resistance in Hepatitis C virus/HIV-coinfected persons: the AIDS Clinical Trials Group A5178 Study. Clinical infectious diseases : an official publication of the Infectious Diseases Society of America. Sep; 2012 55(5):631-638. [PubMed: 22563020]

65. Romero-Gomez M, Fernandez-Rodriguez CM, Andrade RJ, et al. Effect of sustained virological response to treatment on the incidence of abnormal glucose values in chronic hepatitis C. Journal of hepatology. May; 2008 48(5):721-727. [PubMed: 18308416]

66. Rauch A, Kutalik Z, Descombes P, et al. Genetic variation in IL28B is associated with chronic hepatitis $\mathrm{C}$ and treatment failure: a genome-wide association study. Gastroenterology. Apr; 2010 138(4):1338-1345. 1345 e1331-1337. [PubMed: 20060832]

67. Noureddin M, Wright EC, Alter HJ, et al. Association of IL28B genotype with fibrosis progression and clinical outcomes in patients with chronic hepatitis C: a longitudinal analysis. Hepatology. Nov; 2013 58(5):1548-1557. [PubMed: 23703931]

68. Kim HC, Nam CM, Jee SH, Han KH, Oh DK, Suh I. Normal serum aminotransferase concentration and risk of mortality from liver diseases: prospective cohort study. Bmj. Apr 24.2004 328(7446):983. [PubMed: 15028636]

69. McOmish F, Chan SW, Dow BC, et al. Detection of three types of hepatitis C virus in blood donors: investigation of type-specific differences in serologic reactivity and rate of alanine aminotransferase abnormalities. Transfusion. Jan; 1993 33(1):7-13. [PubMed: 7678709] 
70. Conry-Cantilena C, VanRaden M, Gibble J, et al. Routes of infection, viremia, and liver disease in blood donors found to have hepatitis $\mathrm{C}$ virus infection. The New England journal of medicine. Jun 27; 1996 334(26):1691-1696. [PubMed: 8637513]

71. Alberti A, Benvegnu L, Boccato S, Ferrari A, Sebastiani G. Natural history of initially mild chronic hepatitis C. Digestive and liver disease : official journal of the Italian Society of Gastroenterology and the Italian Association for the Study of the Liver. Oct; 2004 36(10):646-654.

72. Hui CK, Belaye T, Montegrande K, Wright TL. A comparison in the progression of liver fibrosis in chronic hepatitis $\mathrm{C}$ between persistently normal and elevated transaminase. Journal of hepatology. Apr; 2003 38(4):511-517. [PubMed: 12663245]

73. Persico M, Persico E, Suozzo R, et al. Natural history of hepatitis C virus carriers with persistently normal aminotransferase levels. Gastroenterology. Apr; 2000 118(4):760-764. [PubMed: 10734027]

74. Nunnari G, Pinzone MR, Cacopardo B. Lack of clinical and histological progression of chronic hepatitis $\mathrm{C}$ in individuals with true persistently normal ALT: the result of a 17-year follow-up. Journal of viral hepatitis. Apr; 2013 20(4):e131-137. [PubMed: 23490382]

75. Mathurin P, Moussalli J, Cadranel JF, et al. Slow progression rate of fibrosis in hepatitis C virus patients with persistently normal alanine transaminase activity. Hepatology. Mar; 1998 27(3):868872. [PubMed: 9500720]

76. Ghany MG, Lok AS, Everhart JE, et al. Predicting clinical and histologic outcomes based on standard laboratory tests in advanced chronic hepatitis C. Gastroenterology. Jan; 2010 138(1):136146. [PubMed: 19766643]

77. Lee MH, Yang HI, Lu SN, et al. Hepatitis C virus seromarkers and subsequent risk of hepatocellular carcinoma: long-term predictors from a community-based cohort study. Journal of clinical oncology : official journal of the American Society of Clinical Oncology. Oct 20; 2010 28(30):4587-4593. [PubMed: 20855826]

78. Pattullo V, Duarte-Rojo A, Soliman W, et al. A 24-week dietary and physical activity lifestyle intervention reduces hepatic insulin resistance in the obese with chronic hepatitis C. Liver international : official journal of the International Association for the Study of the Liver. Mar; 2013 33(3):410-419. [PubMed: 23278982]

79. Abd El-Kader SM, Al-Jiffri OH, Al-Shreef FM. Liver enzymes and psychological well-being response to aerobic exercise training in patients with chronic hepatitis C. African health sciences. Jun; 2014 14(2):414-419. [PubMed: 25320592]

80. McKenna O, Cunningham C, Gissane C, Blake C. Management of the extrahepatic symptoms of chronic hepatitis $\mathrm{C}$ : feasibility of a randomized controlled trial of exercise. American journal of physical medicine \& rehabilitation/Association of Academic Physiatrists. Jun; 2013 92(6):504512 .

81. Thomas DL, Astemborski J, Vlahov D, et al. Determinants of the quantity of hepatitis C virus RNA. The Journal of infectious diseases. Mar; 2000 181(3):844-851. [PubMed: 10720503]

82. Yamada M, Kakumu S, Yoshioka K, et al. Hepatitis C virus genotypes are not responsible for development of serious liver disease. Digestive diseases and sciences. Feb; 1994 39(2):234-239. [PubMed: 8313803]

83. Yeo AE, Ghany M, Conry-Cantilena C, et al. Stability of HCV-RNA level and its lack of correlation with disease severity in asymptomatic chronic hepatitis $\mathrm{C}$ virus carriers. Journal of viral hepatitis. Jul; 2001 8(4):256-263. [PubMed: 11454176]

84. De Moliner L, Pontisso P, De Salvo GL, Cavalletto L, Chemello L, Alberti A. Serum and liver HCV RNA levels in patients with chronic hepatitis C: correlation with clinical and histological features. Gut. Jun; 1998 42(6):856-860. [PubMed: 9691926]

85. Gervais A, Martinot M, Boyer N, et al. Quantitation of hepatic hepatitis C virus RNA in patients with chronic hepatitis C. Relationship with severity of disease, viral genotype and response to treatment. Journal of hepatology. Sep; 2001 35(3):399-405. [PubMed: 11592602]

86. Messina JP, Humphreys I, Flaxman A, et al. Global distribution and prevalence of hepatitis C virus genotypes. Hepatology. Jan; 2015 61(1):77-87. [PubMed: 25069599] 
87. Probst A, Dang T, Bochud M, Egger M, Negro F, Bochud PY. Role of hepatitis C virus genotype 3 in liver fibrosis progression--a systematic review and meta-analysis. Journal of viral hepatitis. Nov; 2011 18(11):745-759. [PubMed: 21992794]

88. Crespo J, Lozano JL, de la Cruz F, et al. Prevalence and significance of hepatitis C viremia in chronic active hepatitis B. The American journal of gastroenterology. Aug; 1994 89(8):1147-1151. [PubMed: 8053425]

89. Kaur S, Rybicki L, Bacon BR, Gollan JL, Rustgi VK, Carey WD. Performance characteristics and results of a large-scale screening program for viral hepatitis and risk factors associated with exposure to viral hepatitis B and C: results of the National Hepatitis Screening Survey. National Hepatitis Surveillance Group. Hepatology. Nov; 1996 24(5):979-986. [PubMed: 8903363]

90. Liang TJ, Bodenheimer HC Jr, Yankee R, et al. Presence of hepatitis B and C viral genomes in US blood donors as detected by polymerase chain reaction amplification. Journal of medical virology. Feb; 1994 42(2):151-157. [PubMed: 8158110]

91. Caccamo G, Saffioti F, Raimondo G. Hepatitis B virus and hepatitis C virus dual infection. World J Gastroenterol. Oct 28; 2014 20(40):14559-14567. [PubMed: 25356020]

92. Tyson GL, Kramer JR, Duan Z, Davila JA, Richardson PA, El-Serag HB. Prevalence and predictors of hepatitis B virus coinfection in a United States cohort of hepatitis C virus-infected patients. Hepatology. Aug; 2013 58(2):538-545. [PubMed: 23505059]

93. Sato $S$, Fujiyama $S$, Tanaka $M$, et al. Coinfection of hepatitis $C$ virus in patients with chronic hepatitis B infection. Journal of hepatology. Aug; 1994 21(2):159-166. [PubMed: 7527435]

94. Di Marco V, Lo Iacono O, Camma C, et al. The long-term course of chronic hepatitis B. Hepatology. Jul; 1999 30(1):257-264. [PubMed: 10385664]

95. Fattovich G, Tagger A, Brollo L, et al. Hepatitis C virus infection in chronic hepatitis B virus carriers. The Journal of infectious diseases. Feb; 1991 163(2):400-402. [PubMed: 1846394]

96. Zarski JP, Bohn B, Bastie A, et al. Characteristics of patients with dual infection by hepatitis B and C viruses. Journal of hepatology. Jan; 1998 28(1):27-33. [PubMed: 9537860]

97. Fong TL, Di Bisceglie AM, Waggoner JG, Banks SM, Hoofnagle JH. The significance of antibody to hepatitis C virus in patients with chronic hepatitis B. Hepatology. Jul; 1991 14(1):64-67. [PubMed: 1648540]

98. Kruse RL, Kramer JR, Tyson GL, et al. Clinical outcomes of hepatitis B virus coinfection in a United States cohort of hepatitis C virus-infected patients. Hepatology. Dec; 2014 60(6):18711878. [PubMed: 25065513]

99. Alter MJ. Epidemiology of viral hepatitis and HIV co-infection. Journal of hepatology. 2006; 44(1 Suppl):S6-9. [PubMed: 16352363]

100. Hernando V, Perez-Cachafeiro S, Lewden C, et al. All-cause and liver-related mortality in HIV positive subjects compared to the general population: differences by HCV co-infection. Journal of hepatology. Oct; 2012 57(4):743-751. [PubMed: 22709620]

101. Daar ES, Lynn H, Donfield S, et al. Relation between HIV-1 and hepatitis C viral load in patients with hemophilia. Journal of acquired immune deficiency syndromes. Apr 15; 2001 26(5):466472. [PubMed: 11391167]

102. Messick K, Sanders JC, Goedert JJ, Eyster ME. Hepatitis C viral clearance and antibody reactivity patterns in persons with haemophilia and other congenital bleeding disorders. Haemophilia : the official journal of the World Federation of Hemophilia. Nov; 2001 7(6):568574. [PubMed: 11851755]

103. Eyster ME, Fried MW, Di Bisceglie AM, Goedert JJ. Increasing hepatitis C virus RNA levels in hemophiliacs: relationship to human immunodeficiency virus infection and liver disease. Multicenter Hemophilia Cohort Study. Blood. Aug 15; 1994 84(4):1020-1023. [PubMed: 8049420]

104. Ghany MG, Leissinger C, Lagier R, Sanchez-Pescador R, Lok AS. Effect of human immunodeficiency virus infection on hepatitis $C$ virus infection in hemophiliacs. Digestive diseases and sciences. Jun; 1996 41(6):1265-1272. [PubMed: 8654162]

105. Rosenthal E, Pialoux G, Bernard N, et al. Liver-related mortality in humanimmunodeficiencyvirus-infected patients between 1995 and 2003 in the French GERMIVIC Joint Study Group 
Network (MORTAVIC 2003 Study). Journal of viral hepatitis. Mar; 2007 14(3):183-188. [PubMed: 17305884]

106. Weber R, Sabin CA, Friis-Moller N, et al. Liver-related deaths in persons infected with the human immunodeficiency virus: the D:A:D study. Archives of internal medicine. Aug 14-28; 2006 166(15):1632-1641. [PubMed: 16908797]

107. Martin-Carbonero L, de Ledinghen V, Moreno A, et al. Liver fibrosis in patients with chronic hepatitis $\mathrm{C}$ and persistently normal liver enzymes: influence of HIV infection. Journal of viral hepatitis. Nov; 2009 16(11):790-795. [PubMed: 19413693]

108. Martinez-Sierra C, Arizcorreta A, Diaz F, et al. Progression of chronic hepatitis C to liver fibrosis and cirrhosis in patients coinfected with hepatitis $C$ virus and human immunodeficiency virus. Clinical infectious diseases : an official publication of the Infectious Diseases Society of America. Feb 15; 2003 36(4):491-498. [PubMed: 12567308]

109. Thein HH, Yi Q, Dore GJ, Krahn MD. Natural history of hepatitis C virus infection in HIVinfected individuals and the impact of HIV in the era of highly active antiretroviral therapy: a meta-analysis. Aids. Oct 1; 2008 22(15):1979-1991. [PubMed: 18784461]

110. Thein HH, Yi Q, Dore GJ, Krahn MD. Estimation of stage-specific fibrosis progression rates in chronic hepatitis C virus infection: a meta-analysis and meta-regression. Hepatology. Aug; 2008 48(2):418-431. [PubMed: 18563841]

111. Seeff LB, Buskell-Bales Z, Wright EC, et al. Long-term mortality after transfusion-associated non-A, non-B hepatitis. The National Heart, Lung, and Blood Institute Study Group. The New England journal of medicine. Dec 31; 1992 327(27):1906-1911. [PubMed: 1454085]

112. Hutchinson SJ, Bird SM, Goldberg DJ. Influence of alcohol on the progression of hepatitis C virus infection: a meta-analysis. Clinical gastroenterology and hepatology : the official clinical practice journal of the American Gastroenterological Association. Nov; 2005 3(11):1150-1159. [PubMed: 16271348]

113. Hezode C, Lonjon I, Roudot-Thoraval F, Pawlotsky JM, Zafrani ES, Dhumeaux D. Impact of moderate alcohol consumption on histological activity and fibrosis in patients with chronic hepatitis C, and specific influence of steatosis: a prospective study. Alimentary pharmacology \& therapeutics. Apr; 2003 17(8):1031-1037. [PubMed: 12694085]

114. Pessione F, Ramond MJ, Njapoum C, et al. Cigarette smoking and hepatic lesions in patients with chronic hepatitis C. Hepatology. Jul; 2001 34(1):121-125. [PubMed: 11431742]

115. Hezode C, Lonjon I, Roudot-Thoraval F, et al. Impact of smoking on histological liver lesions in chronic hepatitis C. Gut. Jan; 2003 52(1):126-129. [PubMed: 12477773]

116. El-Zayadi AR, Selim O, Hamdy H, El-Tawil A, Moustafa H. Heavy cigarette smoking induces hypoxic polycythemia (erythrocytosis) and hyperuricemia in chronic hepatitis $\mathrm{C}$ patients with reversal of clinical symptoms and laboratory parameters with therapeutic phlebotomy. The American journal of gastroenterology. May; 2002 97(5):1264-1265. [PubMed: 12014742]

117. Marrero JA, Fontana RJ, Fu S, Conjeevaram HS, Su GL, Lok AS. Alcohol, tobacco and obesity are synergistic risk factors for hepatocellular carcinoma. Journal of hepatology. Feb; 2005 42(2): 218-224. [PubMed: 15664247]

118. Hezode C, Roudot-Thoraval F, Nguyen S, et al. Daily cannabis smoking as a risk factor for progression of fibrosis in chronic hepatitis C. Hepatology. Jul; 2005 42(1):63-71. [PubMed: 15892090]

119. Hezode C, Zafrani ES, Roudot-Thoraval F, et al. Daily cannabis use: a novel risk factor of steatosis severity in patients with chronic hepatitis C. Gastroenterology. Feb; 2008 134(2):432439. [PubMed: 18242211]

120. Ishida JH, Peters MG, Jin C, et al. Influence of cannabis use on severity of hepatitis C disease. Clinical gastroenterology and hepatology : the official clinical practice journal of the American Gastroenterological Association. Jan; 2008 6(1):69-75. [PubMed: 18166478]

121. Casiglia E, Spolaore P, Ginocchio G, Ambrosio GB. Unexpected effects of coffee consumption on liver enzymes. European journal of epidemiology. May; 1993 9(3):293-297. [PubMed: 8104822]

122. Honjo S, Kono S, Coleman MP, et al. Coffee consumption and serum aminotransferases in middle-aged Japanese men. Journal of clinical epidemiology. Aug; 2001 54(8):823-829.

[PubMed: 11470392] 
123. Ruhl CE, Everhart JE. Coffee and caffeine consumption reduce the risk of elevated serum alanine aminotransferase activity in the United States. Gastroenterology. Jan; 2005 128(1):24-32. [PubMed: 15633120]

124. Modi AA, Feld JJ, Park Y, et al. Increased caffeine consumption is associated with reduced hepatic fibrosis. Hepatology. Jan; 2010 51(1):201-209. [PubMed: 20034049]

125. Seeff LB, Curto TM, Szabo G, et al. Herbal product use by persons enrolled in the hepatitis C Antiviral Long-Term Treatment Against Cirrhosis (HALTC) Trial. Hepatology. Feb; 2008 47(2): 605-612. [PubMed: 18157835]

126. Freedman ND, Curto TM, Morishima C, et al. Silymarin use and liver disease progression in the Hepatitis C Antiviral Long-Term Treatment against Cirrhosis trial. Alimentary pharmacology \& therapeutics. Jan; 2011 33(1):127-137. [PubMed: 21083592]

127. Fried MW, Navarro VJ, Afdhal N, et al. Effect of silymarin (milk thistle) on liver disease in patients with chronic hepatitis $\mathrm{C}$ unsuccessfully treated with interferon therapy: a randomized controlled trial. Jama. Jul 18; 2012 308(3):274-282. [PubMed: 22797645]

128. Arase Y, Ikeda K, Murashima N, et al. The long term efficacy of glycyrrhizin in chronic hepatitis C patients. Cancer. Apr 15; 1997 79(8):1494-1500. [PubMed: 9118029] 


\section{Key Points}

- The incidence of chronic hepatitis $\mathrm{C}$ is declining in the United States but rates of cirrhosis and hepatocellular carcinoma are projected to increase over the next decade.

- $\quad$ Approximately $20-25 \%$ of subjects with chronic hepatitis $\mathrm{C}$ will progress to cirrhosis over 25-30 years.

- The outcome of chronic hepatitis $\mathrm{C}$ is highly variable and influenced by many host, viral and environmental factors, many of which cannot be modifiable 


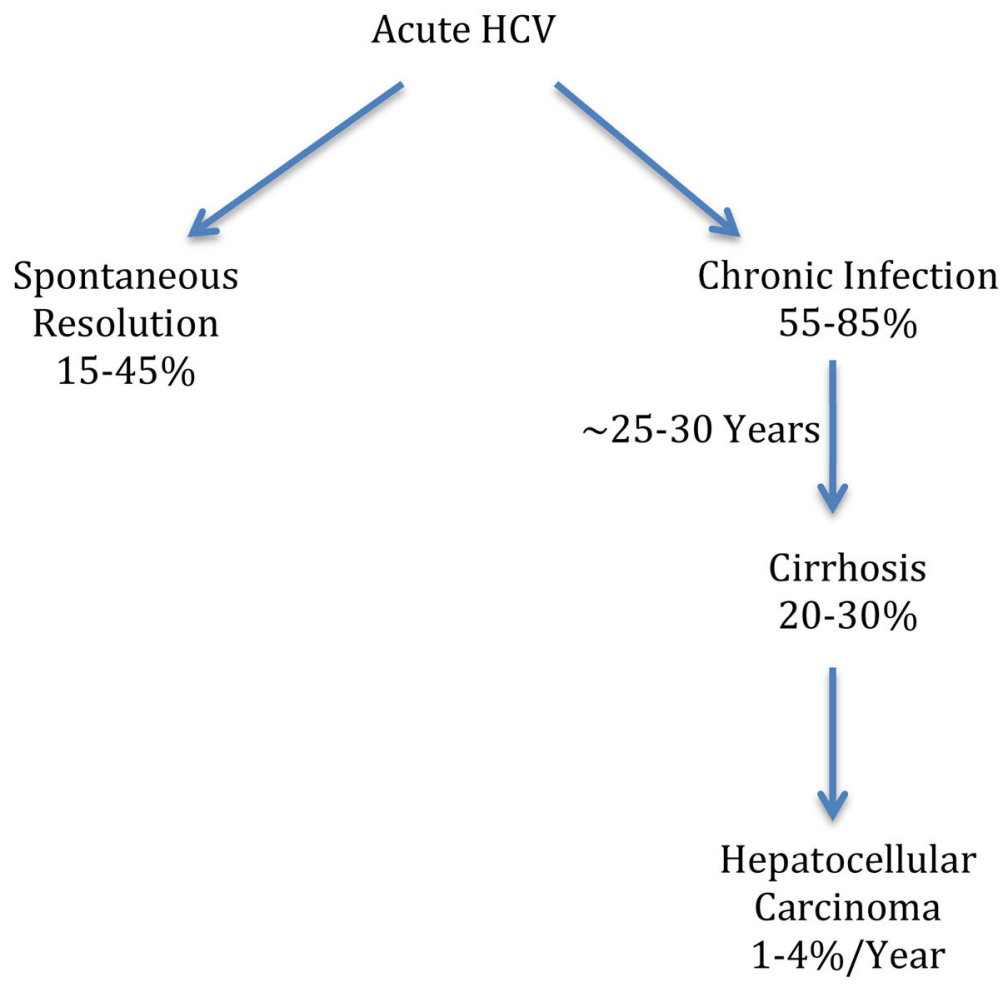

Figure 1.

Natural History of Hepatitis C Virus Infection.

Following exposure to hepatitis $\mathrm{C}$ virus, an acute hepatitis ensues. About $20 \%$ present with jaundice but the majority are asymptomatic. Spontaneous resolution occurs in $15-45 \%$. The remainder develop a chronic hepatitis with a variable course. Cirrhosis develops in approximately $20-30 \%$ of subjects over a 25-30 year period. Once cirrhosis develops patients are at risk for hepatic decompensation, hepatocellular carcinoma and liver-related death. 
Table 1

Factors That Affect The Natural History Of Chronic Hepatitis C

\begin{tabular}{|l|l|l|}
\hline Host Factors & Viral Factors & Environmental Factors \\
\hline Age at infection & Viral load & Alcohol \\
\hline Gender & Genotype & Smoking \\
\hline Race & Co-infection with HBV & Cannabis use \\
\hline Obesity & Co-infection with HIV & Caffeine \\
\hline Steatosis & & \\
\hline Insulin resistance & & \\
\hline Diabetes & & \\
\hline Genetics & & \\
\hline ALT levels & & \\
\hline Exercise & & \\
\hline
\end{tabular}

